\title{
Noneconomic damages due to physical and sexual assault: estimates from civil jury awards
}

\author{
Ted R. Miller ${ }^{1}$, Mark A. Cohen ${ }^{2}$ and Delia Hendrie ${ }^{3}$ \\ ${ }^{1}$ Principal Research Scientist, Pacific Institute for Research and Evaluation, Calverton, MD 20705, (240) 441-2890, USA \\ ${ }^{2} J u s t i n$ Potter Professor of American Competitive Enterprise and Professor of Law, Owen Graduate School of Management, Vanderbilt University, Nashville, USA \\ ${ }^{3}$ School of Public Health, Curtin University, Perth, Australia
}

\begin{abstract}
This paper presents a detailed study of jury awards for compensatory damages to victims of crime. Such awards typically result when victims sue third parties who are responsible for some form of negligence such as inadequate security or alcohol over-service. We obtained nationwide data on jury awards to crime victims and examined the relationship between physical losses, medical costs, offender and victim characteristics, and the ultimate compensatory jury award. Despite the large variability in jury awards, we were able to explain $45 \%-50 \%$ of the variation in the natural log of jury awards for physical assault. The awards systematically vary with the severity of physical injuries sustained by the victim. Considerably more variation is found in the case of sexual assault. We use our regressions to construct estimates of noneconomic damages - the pain, suffering and reduced quality of life endured by the average victim of violent crime in the U.S.
\end{abstract}

\section{Introduction}

Despite the ongoing interest in tort reform, with many states having adopted reforms such as caps on noneconomic or punitive damages, surprisingly few empirical studies analyze U.S. jury awards [1]. Too much of what we know about jury awards is through anecdotal evidence in the popular media. In particular, jury awards are often characterized as being out of control [2], partly due to some multi-million dollar awards that make headlines, even if they are subsequently reduced by the court. The lack of strong empirical research is especially telling if one focuses on the more judgmental aspect of compensatory damages - "noneconomic damages" that compensate pain, suffering and lost quality of life. Leaving aside studies of medical malpractice and of punitive damages, only a handful of studies used large samples of jury awards and modeled factors that explained the size of noneconomic damage awards [1-8].

Several previous studies have looked at civil jury awards related to intentional criminal behavior. Although Cohen [9] used jury awards to estimate "pain and suffering" to crime victims, it based its estimates on regression coefficients by type of injury in automobile crash cases. Rajkumar and French [10] and McCollister et al. [11] followed Cohen's methods and underlying automobile crash jury award data to estimate updated "intangible losses" for various crimes. Miller et al. [12] improved on this approach by analyzing 1,106 jury awards for physical assaults and 361 cases of sexual assault to estimate "pain and suffering" of victims based on actual criminal victimizations. Cohen and Miller [13] analyzed 514 of the 1,106 jury awards for physical assault (and separately 728 for product liability) with a focus on estimating how much juries were willing to award for a lifetime of quality of life. They focused on predicting noneconomic damage awards from functional capacity losses typically associated with physical injuries comparable to the plaintiff's, as well as characteristics of the plaintiff, defendant, and injury event. Smith et al. [14] applied a similar model to 323 drunken driving awards and settlements. Roman [15] estimated noneconomic losses for a range of crimes by combining data on 603 jury awards during 1985-1999 for violent and property crimes with 2003 National Incidence-Based Reporting System data on the distributions of physical injuries and property losses by type of crime. In addition, several authors outside the U.S. context have used jury awards to estimate the cost of crime in other countries - notably Australia [16] where jury awards in transport cases were used as a benchmark, and Canada [17] where average civil awards to crime victims of assault and sexual assault were used to benchmark awards for other crimes based on the length of prison sentences meted out for each crime type.

This paper reports on a detailed analysis of jury awards for compensatory damages to victims of crime. Victims may sue perpetrators and/or third parties who are responsible for some form of negligence that contributed to the criminal act. Although the underlying injury was an intentional crime, compensation is made through civil tort actions. Third party liability may be assessed, for example, to hotel or apartment buildings for inadequate security or lighting, or to employers whose workers commit a violent crime while working [18].

For the U.S., the most recent noneconomic damage estimates for crime are based on a 2003 crime profile. This study's purpose is to characterize noneconomic damages in typical jury awards for intentional injury, excluding wage and medical losses. In part, this paper moves the unpublished methods and data underlying the noneconomic loss estimates reported in ref. [12] into the peer-reviewed literature. We focus on the extent to which noneconomic damage

Correspondence to: Ted R. Miller, Principal Research Scientist, Pacific Institute for Research and Evaluation, Calverton, MD 20705, (240) 441-2890, USA, E-mail: miller@pire.org

Received: December 14, 2016; Accepted: January 17, 2017; Published: January 20, 2017 
awards can be predicted by past and future wage and medical losses and other characteristics of the victim and offender. We then combine these data with current national incidence data to construct estimates of the pain, suffering and reduced quality of life endured by the average victim of violent crime in the U.S.

\section{Methods}

\section{Jury verdict data for intentional injuries}

The primary source of data used in this study was Jury Verdict Research (JVR), now owned by Thomson Reuters. JVR attempts to obtain all awards - whether small or large. They relied on a variety of sources including attorneys who subscribe to their services, plus court officers and students who routinely provide information to the firm. Their data base contains hundreds of thousands of jury awards and settlements from around the country.

We purchased and manually coded a data set from one paragraph summaries of 1,467 jury awards and settlements between 1980-1991 involving physical or sexual assault (excluding cases of wrongful death). We classified about $75 \%(1,106)$ of the cases as physical assaults, and the remaining 361 cases as sexual assault. We coded data about the plaintiff, defendant, event, and injuries, as well as past medical expenses, past wage losses, and noneconomic damages. We converted all dollar amounts to 1990 dollars, using a medical price adjuster for medical expenses and a wage adjuster for all other losses. After we developed an equation for predicting noneconomic damages, following $[12,19,20]$, we applied it to the 2010-2015 national profile of crime victimizations, then used a wage adjuster to restate the damages in 2015 dollars.

About $72 \%$ of the JVR cases contained information on the state and/or county in which the trial was held. These JVR cases represented 313 different counties - only about $10 \%$ of the counties in the U.S. However, FBI Uniform Crime Report data show these 313 counties accounted for $71.4 \%$ of the reported violent crime in the U.S.

Inspecting the coded data revealed the jury awards were not normally distributed, with mean awards of 3-10 times median awards. The data included a few very large awards and many smaller ones. A normal probability plot confirmed the non-normality of both total awards and compensatory awards. A lognormal distribution fit the data quite well, although a few outliers still existed after this transformation. Our analyses, therefore, used log-linear regression.

\section{Representativeness of JVR data}

JVR data are reported voluntarily, which limits the range of their application and raises concerns about their representativeness. They largely exclude verdicts for the defense and settlements, which means they cannot be used to look at settlement rates or tort liability disposition patterns. Because reporting became more complete and more representative over time, they also cannot be used to examine trends in jury awards. Although JVR data are often used by trial lawyers and insurance adjusters to estimate the "value" of particular cases, they are suspected of capturing large awards more frequently than small awards. For these reasons, some analysts of tort liability issues are dismissive of JVR analyses [21-23].

JVR data, however, are appropriate for our purposes. There is no reason to think that the relationship between past losses and noneconomic losses in JVR data would be atypical or that it would differ from the relationship in settlements. Notably, Vidmar [3] concludes JVR data are appropriate for analyzing the relationship between injury severity and jury award. Where JVR data are questionable is in the severity distribution of the assaults they capture. We dealt with that problem by substituting average medical and work loss data from a national study of crime incidence and costs [12] into the regression equation predicting noneconomic damages.

Several studies have examined if JVR data are biased empirically by comparing JVR summary data to sources that are $100 \%$ inclusive for a selected jurisdiction. A good deal of the criticism in that regard may not apply to the time period covered by most of our data [22,23]. For example, in a widely cited criticism of the JVR data, Localio [23] reported that JVR's mean malpractice award of $\$ 962,258$ in 1982 was considerably higher than the $\$ 257,222$ mean award reported by other sources in California. In response, JVR data changed considerably starting in the mid-1980s, reflecting a concerted attempt to be comprehensive. By 1991, the company collected approximately 18,000 jury verdicts annually from around the country, on the order of half of all tort liability verdicts. Tabarrok and Helland [24] reported on several statistical tests that they felt justified using JVR data as nationally representative. Similarly, Bovbjerg, Sloan and Blumstein's [25] comparison of JVR data to all personal injury jury awards in Florida and Kansas City from 1973-1987 indicated JVR cases were typical. The median award of $\$ 82,000$ and mean award of $\$ 490,000$ (in 1987 dollars) in the comprehensive data were similar to the JVR median of $\$ 75,000$ and mean of $\$ 514,339$ in 1989. A related study [26] calculated the mean award in 1985 for medical malpractice cases was $\$ 1.5$ million (in 1990 dollars) compared to JVR's \$1.43 million. Kritzer [21], however, found that the JVR mean tort award in 2001 probably far exceeded the allverdict mean.

\section{Regression analysis of jury awards}

One problem with the JVR dataset is that past and future losses are only sporadically reported. Among the 1106 assault cases we analyzed, past and future medical and wage losses were reported in $60 \%(n=670)$ of the cases. Many cases do report zero medical and/or wage losses, so failure to report does not necessarily mean zero loss. Indeed, many cases without reported monetary losses involved serious injuries. In order to maintain the richness of the full dataset (which includes many different types of injuries), we estimated past and future losses for the $40 \%$ with missing data. To do this, we estimated a regression equation where the sum of past and future monetary loss was the dependent variable, and the independent variables were primarily the types of injuries. We included settlements in this part of the analysis. By multiplying each coefficient by its corresponding case-specific value, we estimated the "predicted" past and future losses for jury verdicts where this information was missing.

In the enhanced data, we hypothesized that jury awards for pain and suffering would be positively related to medical and wage losses. In addition, other factors are likely to influence the ultimate jury award. One possibility is that juries will take into account who is paying - the "deep pocket" effect. They may also be more sympathetic to victims who did not know their attackers, and less sympathetic to those who somehow precipitated the assault. We used multiple lognormal regression to control for some of these factors and to determine the relationship between medical and wage losses and pain and suffering.

\section{Incorporating representative crime data}

Even if JVR's crime data were representative of the cases brought to trial, there is no reason to believe they are representative of criminal victimizations in general. First, few victimizations lend themselves to civil suits. The ability to sue for damages depends on whether a liable 
party has adequate assets to warrant suit. This may vary by state, as legal precedents concerning the liability of third parties may vary considerably $[18,27]$. Differences in legal definitions of compensable damages and tort reform efforts that limit damages also cause jury awards to vary by state [28-32].

We therefore estimated average non-economic losses for physical and sexual assaults by entering national average demographics and estimates of medical costs and wage losses resulting from victimization [12] into the regression equations. We made these estimates by diagnosis group and place of treatment as reported in the NCVS and whether the victimization represented intimate partner violence (IPV). The 10 diagnosis groups used in these calculations were gunshot wound, broken bones plus internal injury, internal injury without broken bones, broken bones without internal injury, knife wound, knocked unconscious, bruises and cuts only, rape only, other specified injury, and not specified. The four places of treatment used were hospital overnight, other medical provider, home, and no medical care received. The medical costs by category in these computations came from causecoded discharge censuses pooled across multiple jurisdictions.
Since the typical crime victim is not the same as the typical crime victim who goes to court to recover damages, these calculations used the demographics for the average crime victim rather than the average from the jury award data. We made separate estimates for subcategories of assault including assault without physical injury and robbery. As appropriate, we varied the losses with victim demographics. For example, by setting the "age 12 and under" variable and the "perpetrator a relative" variables equal to one and variables for other ages and relationships to 0 and using wage losses specific to someone under age 12, we estimated non-economic loss for maltreatment of children under age 12. Similarly, we examined awards for gunshot victims by setting the gunshot variable equal to 1 .

Roman [15] incorrectly reports some aspects of these computations. Notably he did not recognize that the distribution of injuries by nature and place of treatment and associated costs which are entered into the regression equation vary by age group, sex, whether the event was intimate partner violence, and for sexual assault versus robbery versus other assault. Each violent crime estimate in Table 1 requires applying the regression equation to 40 different nature-place combinations, then

Table 1. Estimated non-economic damages and victim demographics by criminal victimization category (in 2015 dollars).

\begin{tabular}{|c|c|c|c|c|c|c|}
\hline Victimization & $\begin{array}{l}\text { Non-Economic } \\
\text { Damages }\end{array}$ & Female & $\begin{array}{l}\text { Age } \\
0-11\end{array}$ & $\begin{array}{c}\text { Age } \\
12-17\end{array}$ & $\begin{array}{c}\text { Age } \\
18-64\end{array}$ & $\begin{array}{c}\text { Age } \\
\text { 65 \& Over }\end{array}$ \\
\hline Homicide [Cohen \& Miller, 13]* & $\$ 5,021,909$ & $21.0 \%$ & $4.9 \%$ & $4.2 \%$ & & $90.9 \%$ \\
\hline Rape & $\$ 204,576$ & $82.6 \%$ & $27.6 \%$ & $18.9 \%$ & & $53.5 \%$ \\
\hline Ages $0-11$ & $\$ 266,098$ & $75.4 \%$ & $100 \%$ & & & \\
\hline Ages 12-17 & $\$ 169,047$ & $85.4 \%$ & & $100 \%$ & & \\
\hline Ages $18 \&$ Over & $\$ 185,423$ & $85.4 \%$ & & & & $100 \%$ \\
\hline Domestic & $\$ 170,658$ & $86.6 \%$ & $0.0 \%$ & $6.5 \%$ & $93.5 \%$ & $0.0 \%$ \\
\hline Robbery & $\$ 10,628$ & $54,2 \%$ & $3.9 \%$ & $10.8 \%$ & $81.9 \%$ & $3.4 \%$ \\
\hline No Injury & $\$ 2,560$ & $51.2 \%$ & $3.9 \%$ & $10.8 \%$ & $81.9 \%$ & $3.4 \%$ \\
\hline With Injury & $\$ 25,286$ & $58.0 \%$ & $3.9 \%$ & $10.8 \%$ & $81.9 \%$ & $3.4 \%$ \\
\hline Domestic & $\$ 25,480$ & $58.0 \%$ & $0.6 \%$ & $27.0 \%$ & $72.4 \%$ & $0.0 \%$ \\
\hline Assault & $\$ 19,627$ & & $3.9 \%$ & $13.8 \%$ & $77.0 \%$ & $5.3 \%$ \\
\hline No Injury & $\$ 3,478$ & $56.0 \%$ & $3.9 \%$ & $13.8 \%$ & $77.0 \%$ & $5.3 \%$ \\
\hline With Injury & $\$ 35,349$ & $57.6 \%$ & $3.9 \%$ & $13.8 \%$ & $77.0 \%$ & $5.3 \%$ \\
\hline Ages $0-11$ & $\$ 25,502$ & $34.6 \%$ & $100 \%$ & & & \\
\hline Ages 12-17 & $\$ 21,253$ & $57.6 \%$ & & $100 \%$ & & \\
\hline Ages $18 \&$ Over & $\$ 39,074$ & $57.6 \%$ & & & $93.6 \%$ & $6.4 \%$ \\
\hline Non-Domestic & $\$ 41,453$ & $57.6 \%$ & $3.9 \%$ & $13.8 \%$ & $77.0 \%$ & $5.3 \%$ \\
\hline Domestic, Ages 18 \& Over & $\$ 34,382$ & $57.6 \%$ & $0.0 \%$ & $17.3 \%$ & $82.5 \%$ & $0.2 \%$ \\
\hline Non-NCVS Domestic & $\$ 24,261$ & $\mathrm{~N} / \mathrm{A}$ & $\mathrm{N} / \mathrm{A}$ & $\mathrm{N} / \mathrm{A}$ & N/A & N/A \\
\hline Medically Treated Non-serial** & $\$ 66,626$ & $58.0 \%$ & $3.9 \%$ & $10.8 \%$ & $81.9 \%$ & $3.4 \%$ \\
\hline Medically Treated**, from Miller et al.'s [34] Impairment Scores & $\$ 66,282$ & & & & & \\
\hline Gunshot, Medically Treated* & $\$ 334,449$ & $51.7 \%$ & $3.9 \%$ & $13.8 \%$ & $77.0 \%$ & $5.3 \%$ \\
\hline Stabbing, Medically Treated* & $\$ 150,060$ & $51.9 \%$ & $3.9 \%$ & $13.8 \%$ & $77.0 \%$ & $5.3 \%$ \\
\hline Child Maltreatment & $\$ 38,846$ & $50.9 \%$ & $69.1 \%$ & $30.9 \%$ & & \\
\hline Sexual Abuse & $\$ 229,722$ & $78.6 \%$ & $62.5 \%$ & $37.5 \%$ & & \\
\hline Physical Abuse & $\$ 93,888$ & $47.1 \%$ & $64.1 \%$ & $35.2 \%$ & & \\
\hline Emotional Abuse & $\$ 15,334$ & $50.8 \%$ & $61.9 \%$ & $38.1 \%$ & & \\
\hline Educational Neglect & $\$ 788$ & $48.4 \%$ & $51.8 \%$ & $48.2 \%$ & & \\
\hline Other Neglect & $\$ 15,971$ & $49.8 \%$ & $72.3 \%$ & $27.7 \%$ & & \\
\hline Larceny & $\$ 550$ & $53.0 \%$ & $1.8 \%$ & $12.8 \%$ & $79.8 \%$ & $5.6 \%$ \\
\hline Burglary & $\$ 543$ & $55.4 \%$ & $0.2 \%$ & $4.8 \%$ & $76.6 \%$ & $18.4 \%$ \\
\hline Motor Vehicle Theft & $\$ 494$ & $52.1 \%$ & $0.0 \%$ & $4.2 \%$ & $90.6 \%$ & $5.2 \%$ \\
\hline Arson, No Injury & $\$ 1,078$ & $50.0 \%$ & $1.9 \%$ & $5.3 \%$ & $90.5 \%$ & $2.3 \%$ \\
\hline Impaired Driving, No Injury & $\$ 2,833$ & $50.0 \%$ & $7.0 \%$ & $14.3 \%$ & $72.7 \%$ & $6.0 \%$ \\
\hline
\end{tabular}

* This estimate is the implied value of life that juries used in valuing nonfatal assaults calculated using the regression equation in [13], net of lifetime work loss and the average medical cost per homicide.

** Live discharge from hospital emergency or inpatient department.

$\mathrm{N} / \mathrm{A}=$ not available.

Demographics from 2015 National Crime Victimization Survey (NCVS), 2010-2014 CDC WISQARS online query system (for medically treated assault counts), and Sedlak [50], with some detailed breakdowns proportioned from recent totals using 1987-1990 NCVS data [12]. 
weighting those combinations together based on the incidence profile for the crime type and age group.

This calculation process generated a series of award estimates corresponding to NCVS injury categories. We subtracted the medical and wage losses from those estimates to arrive at the non-economic loss by injury type. For example, the estimated non-economic loss for a rape victim over age 12 with broken bones or internal injuries is $\$ 154,202$. A similar rape victim who requires no medical care and whose only injury is the rape itself, has an estimated non-economic loss of $\$ 75,330$. We combined these individual estimates with NCVS population proportions (e.g., the percentage of IPV rape victims who require medical care for broken bones or internal injuries) to arrive at an average non-economic loss estimate over all victims. We drew the necessary data on frequency of injury, age of victim, etc., from the 2015 NCVS plus older NCVS data [12] for some detailed breakdowns by injury type, We used the WISQARS online data analysis tool provided by CDC (https://www.cdc.gov/injury/wisqars/) to get 2011-2014 data by age group on medically treated physical assault and on gunshot and knife wounds; the 2010 National Incidence Survey on Child Abuse and Neglect (the most recent available) for data on child maltreatment; and an injury distribution drawn from medical discharge data [12] for the children under 12 not covered by NCVS. We averaged four years of WISQARS data because the sample is thin.

\section{Results}

Table 2 contains summary statistics on the jury verdict cases. While about $10 \%$ of the assault cases were against minors, $35 \%$ of sexual assault victims were minors. Most of the physical assault victims were male $(76 \%)$, while most sexual assault victims were female (83\%). Nearly all offenders (95-99\%) were male. In most instances, we were able to identify the relationship between the offender and victim. The largest percentage were either complete strangers $(72 \%$ for physical and $59 \%$ for sexual assaults) or non-strangers who were not related in any way to the victim (23-33\%). Few cases involved a spouse, parent or other relative.

Weapons were used in about $39 \%$ of assault cases, with $23 \%$ being gunshots, $8 \%$ knives, and $8 \%$ hit by other objects. In contrast, only 5 cases (less than 1\%) of sexual assault involved any form of weapons. Multiple offenders were involved in about $11 \%$ of the physical assault cases and $7 \%$ of sexual assaults. The plaintiff had some form of involvement in $42 \%$ of physical assault cases - ranging from allegations by the defendant that the plaintiff was somehow involved to plaintiff precipitation, compared to about $10 \%$ for sexual assaults. About half the sexual assault cases (54\%) involved completed rape, with the remaining $46 \%$ being attempted rape or other forms of sexual assault.

Table 3 presents summary statistics for past and future dollar losses alleged by the plaintiff, as well as the respective jury awards for physical assaults. Detailed information on the size of compensatory damage awards (as distinct from punitive damage or loss of consortium awards) was available in 956 of 976 cases. The mean jury award (in 1990 dollars) was $\$ 682,629$, while the median award was $\$ 59,276$. The largest component of the mean and median award was for compensatory damages. In theory, compensatory damages are designed to compensate the victim for out-of-pocket losses plus non-economic losses. They are not designed to punish the offender or compensate third parties. The mean compensatory jury award was $\$ 545,683$, while the median compensatory award was $\$ 49,449$.

Although more than $97 \%$ of tort lawsuits in the U.S. that are not
Table 2. Descriptive statistics: physical and sexual assault cases.

\begin{tabular}{|c|c|c|c|c|}
\hline \multirow[b]{2}{*}{ Category: Item } & \multicolumn{2}{|c|}{$\begin{array}{l}\text { Physical Assault } \\
(\mathrm{n}=1106)\end{array}$} & \multicolumn{2}{|c|}{ Sexual Assault $(n=361)$} \\
\hline & Number & $\begin{array}{l}\text { Fraction of } \\
\text { Category }\end{array}$ & Number & $\begin{array}{l}\text { Fraction of } \\
\text { Category }\end{array}$ \\
\hline Verdict Type: Trial & 976 & 0.882 & 277 & 0.767 \\
\hline Settlement & 130 & 0.118 & 84 & 0.233 \\
\hline Age of Victim: Under 13 & 27 & 0.033 & 64 & 0.211 \\
\hline Age 13-18 & 54 & 0.065 & 44 & 0.145 \\
\hline Age 19-35 & 450 & 0.543 & 139 & 0.457 \\
\hline Age $36-55$ & 221 & 0.267 & 49 & 0.161 \\
\hline Age 56-65 & 45 & 0.054 & 3 & 0.01 \\
\hline Over Age 65 & 25 & 0.03 & 5 & 0.016 \\
\hline Sex of Victim: Male & 831 & 0.763 & 61 & 0.172 \\
\hline Female & 258 & 0.237 & 293 & 0.828 \\
\hline \multicolumn{5}{|l|}{ Employment Status of Victim: } \\
\hline Unemployed & 33 & 0.051 & 25 & 0.129 \\
\hline Student & 93 & 0.143 & 84 & 0.433 \\
\hline Homemaker & 12 & 0.018 & 5 & 0.026 \\
\hline Retired & 25 & 0.038 & 4 & 0.021 \\
\hline Employed & 487 & 0.749 & 76 & 0.392 \\
\hline \multicolumn{5}{|l|}{ Relationship of Offender/Victim: } \\
\hline Complete Stranger & 770 & 0.716 & 211 & 0.591 \\
\hline Spouse/Ex-Spouse & 27 & 0.025 & 3 & 0.008 \\
\hline Parent/Step-Parent & 8 & 0.007 & 19 & 0.053 \\
\hline Other Relative & 6 & 0.006 & 2 & 0.006 \\
\hline Boy/Girlfriend & 18 & 0.017 & 3 & 0.08 \\
\hline Other Known Nonrelative & 248 & 0.231 & 119 & 0.333 \\
\hline Type of Attack: No Physical Contact & 36 & 0.033 & 6 & 0.017 \\
\hline Body Contact Only & 625 & 0.566 & 350 & 0.97 \\
\hline Shot at w/Gun & 255 & 0.231 & 3 & 0.008 \\
\hline Stabbed/Cut with Knife & 89 & 0.081 & 0 & 0 \\
\hline Hit by Other Object & 88 & 0.08 & 2 & 0.006 \\
\hline Other & 11 & 0.01 & 0 & 0 \\
\hline Completed Rape & - & -- & 195 & 0.54 \\
\hline Other Sexual Assault & -- & -- & 166 & 0.46 \\
\hline Number of Offenders: One & 865 & 0.89 & 303 & 0.927 \\
\hline Two & 72 & 0.074 & 13 & 0.04 \\
\hline Three or More & 35 & 0.036 & 11 & 0.033 \\
\hline Sex of Offender: Male & 856 & 0.951 & 340 & 0.991 \\
\hline Female & 44 & 0.049 & 3 & 0.009 \\
\hline \multicolumn{5}{|l|}{ Plaintiff/Offender Involvement } \\
\hline Passive/No Involvement & 664 & 0.582 & 325 & 0.9 \\
\hline Alleged Plaintiff Involvement & 266 & 0.241 & 34 & 0.094 \\
\hline Parties Arguing & 134 & 0.121 & 0 & 0 \\
\hline Plaintiff Precipitated & 12 & 0.011 & 0 & 0 \\
\hline Other & 50 & 0.045 & 2 & 0.006 \\
\hline $\begin{array}{l}\text { Type of Defendant: } \\
\text { Individual Offender Only }\end{array}$ & 462 & 0.418 & 100 & 0.279 \\
\hline Individual Third Party Only & 23 & 0.021 & 15 & 0.042 \\
\hline Business Only & 275 & 0.249 & 139 & 0.387 \\
\hline Government Only & 61 & 0.055 & 28 & 0.078 \\
\hline Other/Combination of Above & 284 & 0.257 & 77 & 0.214 \\
\hline
\end{tabular}

dropped are settled out-of-court [28,29], only $11.8 \%$ of JVR cases involve settlements. Unlike jury awards, JVR does not attempt to systematically collect out-of-court settlements. Indeed, settlement data are not included in their published handbooks. Thus, they are much less likely to be representative, and more likely to be biased in favor of more significant or interesting cases. Settlements for the 130 assault cases were actually smaller than jury awards, with the average settlement being $\$ 184,061$, while the median was $\$ 30,000$ (in 1990 dollars).

Table 4 contains similar information for rape and sexual assault cases. Both the mean and median jury award for rape and sexual assault were considerably higher than for physical assault. The mean 
Table 3. Victim losses, jury awards and settlements: physical assaults, in 1990 dollars.

\begin{tabular}{|c|c|c|c|c|}
\hline & \# Cases & Mean* & Median* & Maximum \\
\hline \multicolumn{5}{|l|}{$\begin{array}{l}\text { JURY AWARDS } \\
(\mathrm{N}=976)\end{array}$} \\
\hline \multicolumn{5}{|l|}{ Alleged Victim Losses } \\
\hline Total Past Losses & 593 & $\$ 37,029$ & $\$ 7,498$ & $\$ 2,632,055$ \\
\hline - Past medical & 528 & 20,328 & 5,400 & $11,32,803$ \\
\hline - Past wages & 271 & 34,423 & 3,432 & $19,24,803$ \\
\hline Total Future Losses & 82 & $4,29,718$ & 98,173 & $56,41,632$ \\
\hline - Future medical & 64 & $3,21,450$ & 20,016 & $43,45,562$ \\
\hline - Future wages & 40 & $3,79,853$ & $2,09,967$ & $55,79,065$ \\
\hline \multicolumn{5}{|l|}{ Jury Award to Victim } \\
\hline Total Award & 976 & $6,82,629$ & 59,276 & $9,72,42,537$ \\
\hline -Compensatory & 956 & $5,45,683$ & 49,449 & $4,74,91,294$ \\
\hline -Punitive & 248 & $5,09,096$ & 22,564 & $4,97,51,244$ \\
\hline -Loss of Consortium & 51 & $1,82,755$ & 29,104 & $15,57,549$ \\
\hline -Other "specials" & 32 & $1,18,949$ & 20,923 & $18,23,318$ \\
\hline $\begin{array}{l}\text { Reduction in Awards } \\
\text { Due to Contributory } \\
\text { Negligence }\end{array}$ & 106 & $1,83,669$ & 23,864 & $55,11,706$ \\
\hline \multicolumn{5}{|c|}{ SETTLEMENTS $(\mathrm{N}=130)$} \\
\hline \multicolumn{5}{|l|}{ Alleged Victim Losses } \\
\hline Total Past Losses & 77 & $\$ 13,740$ & $\$ 3,483$ & $\$ 353,043$ \\
\hline - Past medical & 67 & 13,432 & 3,336 & $3,53,043$ \\
\hline - Past wages & 32 & 3,115 & 1,249 & 22,316 \\
\hline Total Future Losses & 10 & $3,97,047$ & 30,985 & $21,70,000$ \\
\hline - Future medical & 9 & $4,39,256$ & 35,391 & $21,70,000$ \\
\hline - Future wages & 2 & 8,585 & 85857 & 17,170 \\
\hline \multicolumn{5}{|l|}{ Settlement Amount } \\
\hline Total Settlement & 130 & $\$ 184,061$ & $\$ 30,000$ & $\$ 3,000,000$ \\
\hline
\end{tabular}

* Mean and Median figures are based on the sample of cases shown in that row. For example, the median punitive damage award was $\$ 22,564$ for the 248 cases in which punitive damages were awarded out of 976 total awards. Thus, the median punitive damage award over all eases was zero.

Table 4. Victim losses and jury awards: rape and sexual assault, in 1990 dollars.

\begin{tabular}{|l|c|c|c|c|}
\hline & \# Cases & Mean* & Median* & Maximum \\
\hline Alleged Victim Losses & & & & \\
\hline Total Past Losses & 107 & $\$ 59,392$ & $\$ 7,138$ & $\$ 1,407,640$ \\
\hline - Past medical & 87 & 24,885 & 5,286 & 283,201 \\
\hline - Past wages & 28 & 126,310 & 18,025 & $1,124,439$ \\
\hline Total Future Losses & 35 & 200,715 & 50,000 & $1,405,244$ \\
\hline - Future medical & 30 & 96,598 & 40,286 & 814,560 \\
\hline - Future wages & 14 & 294,793 & 235,724 & $1,080,756$ \\
\hline Jury Award to Victim & & & & \\
\hline Total Award & 276 & $1,525,626$ & 430,285 & $47,468,354$ \\
\hline -Compensatory & 267 & $1,040,623$ & 373,134 & $23,734,177$ \\
\hline -Punitive & 80 & $1,644,973$ & 170,700 & $23,734,177$ \\
\hline -Loss of Consortium & 26 & 305,783 & 96,947 & $2,167,414$ \\
\hline -Other "specials" & 9 & 541,533 & 35,000 & $1,478,463$ \\
\hline Reduction in Awards & 21 & 336,475 & 161,464 & $2,206,636$ \\
\hline \begin{tabular}{l} 
Dut Contibut \\
\hline
\end{tabular} & & & & \\
\hline
\end{tabular}

Negligence

* Mean and Median figures are based on the sample of cases shown in that row. For example, the median punitive damage award was $\$ 170,700$ for the 80 cases in which punitive damages were awarded out of 276 total awards. Thus, the median punitive damage award over all eases was zero.

compensatory award for rape and sexual assault cases was $\$ 1,040,623$, with the median being $\$ 373,124$ (in 1990 dollars).

Another way to examine the representativeness of the JVR data is to compare the characteristics of the typical plaintiff in JVR to the typical crime victim in the U.S. We compared JVR data with contemporaneous
National Crime Victimization Survey (NCVS) data (http://www. bjs.gov/index.cfm?ty=nvat). NCVS is the government's nationally representative household survey designed to estimate the extent and nature of criminal victimization. Although the NCVS and JVR data had many similarities, JVR cases generally involved more serious injuries. For example, JVR victims of physical (nonsexual) assault were more likely than NCVS victims to have been shot (23\% versus $0.2 \%$ ), more likely to have broken bones ( $27 \%$ versus $2 \%$ ), and less likely to have experienced only minor cuts or bruises or no physical injury at all (15\% versus $55 \%)$. Similarly, JVR victims had higher medical costs than Miller et al.'s estimated NCVS victims [13].

\section{Estimation of past and future losses}

Table 5 reports the regression results for past and future losses; the dependent variable is the natural log of past and future medical and wage losses (in constant 1990 dollars). In the case of physical assaults, the results were quite encouraging, as the independent variables were able to explain $45 \%-50 \%$ of the variance in the natural log of past and future losses.

In the case of sexual assaults, the regression equations were only able to explain $15 \%$ of the variance in the natural log of past and future losses. One reason may be lack of complete reporting. Unlike physical assaults in which about $60 \%$ of the cases reported monetary losses, only about $35 \%$ of sexual assault cases reported monetary losses. Another

Table 5. Estimation of past and future wage and medical losses dependent variable $=\mathrm{Ln}$ (in 1990 Dollars)

\begin{tabular}{|l|c|c|c|c|}
\hline Independent Variables & $\begin{array}{c}\text { Physical } \\
\text { Assault }\end{array}$ & t-statistic & $\begin{array}{c}\text { Sexual } \\
\text { Assault/ } \\
\text { Rape }\end{array}$ & t-statistic \\
\hline Constant & 7.493 & $38.1 * *$ & 6.89 & $11.08^{* *}$ \\
\hline Plaintiff Employed & 0.111 & 0.66 & 0.92 & $2.65^{* *}$ \\
\hline Aggravation of Existing Condition & 0.473 & 1.17 & -1.81 & -1.74 \\
\hline Serious Multiple Injuries & 1.726 & 1.19 & 5.56 & $2.50^{*}$ \\
\hline Loss of Finger(s) or Toe(s) & 2.515 & 1.74 & -- & -- \\
\hline Amputation of Limb(s) & 3.268 & $2.26^{*}$ & -- & -- \\
\hline Burn & 0.273 & 0.32 & -- & -- \\
\hline Paralyzed & 4.199 & $10.86^{* *}$ & -- & -- \\
\hline Leg or Foot Fracture & 1.716 & $6.02^{* *}$ & -- & -- \\
\hline Arm or Hand Fracture & 0.788 & 1.82 & 0.69 & 0.41 \\
\hline Slight Injury to Senses & -0.667 & -2.04 & -0.06 & -0.03 \\
\hline Moderate to Severe Brain Damage & 2.948 & $8.42^{* *}$ & -- & -- \\
\hline Back Injury (except fractures) & 0.908 & $3.31^{* *}$ & -- & -- \\
\hline Facial Scarring & 0.835 & $2.10^{*}$ & -- & -- \\
\hline Sexual Impairment & 0.446 & 0.43 & -1.16 & -0.68 \\
\hline Loss of Sight or Hearing & 1.466 & $5.94^{* *}$ & -1.28 & -0.66 \\
\hline Head, Neck or Jaw Fracture & 1.405 & $4.90^{* *}$ & 4.69 & $2.47^{* *}$ \\
\hline Nerve Injury & 0.963 & $3.20^{* *}$ & 0.27 & 0.15 \\
\hline Injury to Limbs & 0.602 & $2.24 *$ & -- & -- \\
\hline Mental Health Injury/PTSD & -0.099 & -0.54 & 1.41 & $2.48^{* *}$ \\
\hline Fracture Back, Hip, Chest, etc. & -0.130 & -0.37 & -- & -- \\
\hline Dental Injury & -0.025 & -0.11 & -- & -- \\
\hline Internal Injury & 1.735 & $7.72^{* *}$ & -- & -- \\
\hline Puncture except Brain/Internal & 0.754 & $3.38^{* *}$ & -- & -- \\
\hline Minor Injury (abrasion, cut, etc) & -0.182 & -1.27 & -0.85 & -1.1 \\
\hline Facial Fracture & 0.813 & $4.57^{* *}$ & 3.43 & $3.74 * *$ \\
\hline Gunshot Wound & 0.858 & $4.58^{* *}$ & 3.47 & $1.95^{*}$ \\
\hline Minor Brain Injury or Concussion & 0.534 & 1.77 & -- & -- \\
\hline Unknown Injury & 0.538 & 1.73 & 1.55 & 1.37 \\
\hline Adjusted R-squared & 661 & & & 0.15 \\
\hline Sample Size & & & 128 & \\
\hline
\end{tabular}


possible reason for this modest explanatory power is that sexual assault victimizations are more likely to involve psychological counseling. In the case of long-term psychological counseling, the amount of past losses will crucially depend on the time between the crime and the lawsuit - and future losses are discounted into the future and are more likely to be challenged by defense counsel than past losses that are observable. In fact, in our sample, the length of time between the crime and lawsuit is larger and more variable for sexual assault cases than for physical assault cases. For the 677 assault cases where the year of crime and year of disposition both are available, the mean number of years is 3.30 with standard deviation 2.00. For the 180 sexual assault cases with both years available, the mean was 4.24 and standard deviation 2.76 .

\section{Regressions predicting damages}

Table 6 reports on two ordinary least squares regressions estimating compensatory damage awards for physical assault cases as a function of predicted past and future medical and wage losses as well as other variables. Settlement data are not included in Table 6. Both compensatory awards and past and future losses are transformed into natural logs. The first equation in Table 6 is based on the full sample of 976 jury awards, while the second one is based on a restricted sample of 956 cases. That smaller sample was obtained by deleting outliers from the first equation. These outliers were observations where the residuals were more than three standard deviations from the mean.
Of the 20 cases eliminated, 17 involved minimum compensation usually $\$ 1$ to $\$ 100$ - where there was an allegation of some involvement by the plaintiff. Usually, these cases were barroom brawls or other fights involving little criminal intent and a high degree of plaintiff involvement if not precipitation. The remaining three cases were clear outliers on the high end -- awards of several million dollars each.

Most coefficients in the two equations are similar. Noteworthy differences are when the offense occurs following an argument between the two parties, when the victim precipitated the offense, and when the two parties had no actual physical contact (i.e., there is only a threat of or attempt at assault). In both cases, eliminating outliers significantly decreases the magnitude of their respective negative coefficients. This is not surprising, since the "outliers" are likely to be cases in which the jury agreed there was an assault, but refused to award large damages due to the circumstances of the offense. The model is an excellent fit, explaining almost half of the variation in awards.

Table 7 reports on a similar analysis of sexual assault and rape cases. Elimination of seven outliers improved the explanatory power of this model, but it still is modest.

\section{Prediction of pain and suffering for crime victims}

Table 1 shows estimated non-economic losses for a range of victimizations including both violent and property crimes. These

Table 6. Estimation of compensatory awards for physical assaults (in 1990 dollars).

\begin{tabular}{|c|c|c|c|c|c|c|}
\hline Variable & $\begin{array}{c}\text { Mean of Variable } \\
\text { (full sample) }\end{array}$ & $\begin{array}{l}\text { Coefficient } \\
\text { (full sample) }\end{array}$ & Standard Error & $\begin{array}{l}\text { Mean of Variable } \\
\text { (w/o outliers) }\end{array}$ & $\begin{array}{l}\text { Coefficient W/o } \\
\text { outliers }\end{array}$ & Standard Error \\
\hline Constant & & 10.99 & $1.91^{* *}$ & & 9.800 & $1.635^{* *}$ \\
\hline Year of Disposition & 87.3 & -0.062 & $0.021^{* *}$ & 87.3 & -0.047 & $0.018^{* *}$ \\
\hline Ln(Past + Future Losses) & 8.79 & 0.627 & $0.036^{* *}$ & 8.08 & 0.609 & $0.031^{* *}$ \\
\hline \multicolumn{7}{|l|}{ OFFENSE-SPECIFIC } \\
\hline Parties were Arguing & 0.125 & -0.885 & $0.198^{* *}$ & 0.120 & -0.542 & $0.171^{* *}$ \\
\hline Series Victimization & 0.004 & 0.209 & 1.006 & 0.004 & 0.168 & 0.855 \\
\hline Multiple Offenders & 0.099 & 0.179 & 0.221 & 0.100 & 0.189 & 0.430 \\
\hline Offender Alcohol/Drug Impaired & 0.058 & 0.041 & 0.271 & 0.060 & -0.061 & 0.231 \\
\hline Victim Alcohol/Drug Impaired & 0.038 & -0.507 & 0.333 & 0.037 & -0.311 & 0.290 \\
\hline Offender Relative or Lover & 0.053 & 0.287 & 0.323 & 0.052 & 0.350 & 0.280 \\
\hline Offender A Stranger & 0.688 & -0.031 & 0.152 & 0.688 & 0.048 & 0.131 \\
\hline \multicolumn{7}{|l|}{ INJURY SPECIFIC } \\
\hline Stabbing & 0.08 & 0.785 & $0.242^{* *}$ & 0.081 & 0.606 & $0.207^{* *}$ \\
\hline Gunshot Wound & 0.24 & 0.841 & $0.171^{* *}$ & 0.243 & 0.751 & $0.146^{* *}$ \\
\hline No Physical Contact & 0.035 & -1.093 & $0.347^{* *}$ & 0.033 & -0.766 & $0.304^{* *}$ \\
\hline Facial Scarring & 0.025 & 0.660 & 0.416 & 0.025 & 0.609 & 0.353 \\
\hline Aggravate Existing Condition & 0.018 & -0.318 & 0.470 & 0.019 & -0.373 & 0.399 \\
\hline \multicolumn{7}{|l|}{ VICTIM SPECIFIC } \\
\hline Female & 0.23 & 0.500 & $0.162 * *$ & 0.233 & 0.285 & $0.139 *$ \\
\hline Age 12 or Under & 0.018 & 0.470 & 0.469 & 0.019 & 0.428 & 0.398 \\
\hline Age 13-18 & 0.053 & -0.026 & 0.283 & 0.053 & 0.022 & 0.242 \\
\hline Age 65 or Older & 0.024 & 0.283 & 0.419 & 0.023 & 0.628 & 0.364 \\
\hline \multicolumn{7}{|l|}{ DEFENDANT SPECIFIC } \\
\hline Only Individual Offender & 0.441 & -0.807 & $0.167^{* *}$ & 0.435 & -0.649 & $0.144^{* *}$ \\
\hline Only Third Party Individual & 0.019 & 0.552 & 0.470 & 0.020 & 0.663 & 0.399 \\
\hline Only Third Party Government & 0.232 & 0.560 & 0.310 & 0.052 & 0.643 & $0.264^{*}$ \\
\hline Only Third Party Business & 0.232 & 0.416 & $0.183^{*}$ & 0.233 & 0.521 & $0.156^{* *}$ \\
\hline Adjusted R-squared & & 0.444 & & & 0.485 & \\
\hline Mean of Dependent Variable & 10.62 & & & 10.764 & & \\
\hline Standard Error & & 1.945 & & & 1.651 & \\
\hline Sample Size & 976 & 976 & & 956 & 956 & \\
\hline
\end{tabular}

* t significant at $\mathrm{p}<0.05 ; * * \mathrm{t}$ significant at $\mathrm{p}<0.01$, In NCVS 2015 , means are 0.221 for offender relative or lover $(0.372$ with injury, 0.150 without), 0.315 for offender a stranger $(0.243$ with injury, 0.423 without), 0.564 for female ( 0.588 with injury; 0.560 without), 0.138 for age $13-18,0.053$ for age 65 or older ( 0.062 with injury; 0.50 without); in multi-year NCVS [ 49 ], means are .088 for series victimization ( 0.0 .63 with injury; 0.099 without). US mean for age $0-12$ is 0.034 [12]. 
Table 7. Estimation of compensatory awards for sexual assault (in 1990 dollars).

\begin{tabular}{|c|c|c|c|c|c|c|}
\hline Variable & $\begin{array}{l}\text { Mean of Variable } \\
\text { (full sample) }\end{array}$ & $\begin{array}{c}\text { Coefficient } \\
\text { (full sample) }\end{array}$ & Standard Error & $\begin{array}{c}\text { Mean of Variable } \\
\text { (w/o outliers) }\end{array}$ & $\begin{array}{c}\text { Coefficient W/o } \\
\text { outliers }\end{array}$ & Standard Error \\
\hline Constant & & 21.74 & $4.97 * *$ & & 16.971 & $3.721 * *$ \\
\hline Year of Disposition & 87.3 & -0.151 & $0.055^{* *}$ & 87.3 & -0.076 & 0.041 \\
\hline Ln(Past + Future Losses) & 8.626 & 0.340 & $0.102 * *$ & 9.048 & 0.249 & $0.074 * *$ \\
\hline \multicolumn{7}{|l|}{ OFFENSE-SPECIFIC } \\
\hline Parties were Arguing & 0.516 & 0.788 & $0.378^{*}$ & 0.519 & 0.757 & $0.275^{* *}$ \\
\hline Series Victimization & 0.119 & 0.904 & 0.589 & 0.122 & 0.398 & 0.424 \\
\hline Multiple Offenders & 0.076 & 0.120 & 0.593 & 0.074 & 0.281 & 0.434 \\
\hline Offender Alcohol/Drug Impaired & 0.011 & 0.245 & 1.50 & 0.011 & -0.003 & 1.079 \\
\hline Victim Alcohol/Drug Impaired & 0.007 & -1.64 & 1.842 & 0.007 & -2.848 & $1.333^{*}$ \\
\hline Offender Relative or Lover & 0.079 & -0.017 & 0.706 & 0.081 & -0.192 & 0.508 \\
\hline Offender A Stranger & 0.556 & 0.213 & 0.422 & 0.556 & 0.123 & 0.309 \\
\hline \multicolumn{7}{|l|}{ INJURY SPECIFIC } \\
\hline Stabbing & 0.004 & 0.787 & 2.533 & 0.004 & 1.378 & 1.820 \\
\hline Gunshot Wound & 0.004 & 0.411 & 2.535 & 0.004 & 0.201 & 1.823 \\
\hline No Physical Contact & 0.018 & 1.435 & 1.116 & 0.019 & 0.738 & 0.833 \\
\hline Facial Scarring & 0.014 & -0.603 & 1.272 & 0.019 & -0.722 & 0.914 \\
\hline Aggravate Existing Condition & 0.018 & -0.318 & 0.470 & 0.019 & -0.373 & 0.399 \\
\hline \multicolumn{7}{|l|}{ VICTIM SPECIFIC } \\
\hline Female & 0.794 & 0.595 & 0.419 & 0.800 & 0.088 & 0.313 \\
\hline Age 12 or Under & 0.181 & 0.347 & 0.458 & 0.178 & 0.339 & 0.332 \\
\hline Age $13-18$ & 0.112 & 0.325 & 0.533 & 0.115 & -0.116 & 0.387 \\
\hline Age 65 or Older & 0.011 & -4.83 & $1.489 * *$ & 0.007 & -0.632 & 1.300 \\
\hline \multicolumn{7}{|l|}{ DEFENDANT SPECIFIC } \\
\hline Only Individual Offender & 0.310 & -1.273 & $0.459 * *$ & 0.307 & -1.112 & $0.335^{* *}$ \\
\hline Only Third Party Individual & 0.025 & -0.576 & 1.036 & 0.026 & -1.024 & 0.747 \\
\hline Only Third Party Government & 0.076 & -0.537 & 0.654 & 0.074 & -0.475 & 0.481 \\
\hline Only Third Party Business & 0.350 & -0.355 & 0.431 & 0.359 & -0.809 & $0.315^{* *}$ \\
\hline Adjusted R-squared & & 0.112 & & & 0.132 & \\
\hline Mean of Dependent Variable & 12.238 & & & 12.527 & & \\
\hline Standard Error & & 2.497 & & & 1.793 & \\
\hline Sample Size & 277 & 277 & & 270 & 270 & \\
\hline
\end{tabular}

figures are combined for attempted and completed crimes. Applying 2010-2015 incidence data and inflating to 2015 dollars, we estimate the highest average non-economic losses are $\$ 334,449$ for a hospitaladmitted gunshot victim, $\$ 204,576$ for sexual assault/rape, $\$ 150,060$ for a hospital-admitted knife wound, $\$ 93,888$ for child physical abuse, $\$ 35,349$ for a victim injured in a physical assault, and $\$ 25,286$ for an injured robbery victim. For those without any physical injury, the estimated monetary value of noneconomic losses is $\$ 3,478$ for assault and $\$ 2,560$ for robbery. Since less than half of assault (including attempted assault) and robbery victims actually are physically injured [15], the average non-economic loss is $\$ 19,627$ over all physical assault victims and $\$ 10,628$ over all robbery victims.

We compared the regression-based estimates of non-economic damages for medically treated assaults (including in robberies) to estimates derived directly from physician estimates of the impairment these injuries typically cause (the impairment fractions analyzed by Cohen and Miller [13]). The two estimates are virtually identical, $\$ 66,587$ from the JVR data and $\$ 66,926$ from the impairment data. That agreement at the mean, however, masks very substantial variations in individual values, with the impairment-based estimates generally exceeding the jury award estimates for admitted victims and below them for victims treated in the emergency department and released. In these calculations, gunshot and cut/stab wounds always came from the jury awards since mechanism-specific impairment ratings were not available for penetrating wounds.

\section{Factors affecting jury awards}

As expected, juries tend to award larger monetary amounts to victims when the injuries they sustain are more severe, and award less when there is little or no physical contact. Tables 5 and 6 contain other findings, however, that likely have little to do with severity of injury. Expressed in constant dollars, mean JVR-reported physical assault and sexual assault victim awards both decreased from 1980 to 1990. This downward trend probably resulted from more representative JVR coverage of jury awards in the later years, prompting us to set the year to 1990 when using the equations to estimate typical damages. We also found evidence consistent with a "deep pocket effect," since lawsuits involving only the perpetrator as a defendant had significantly lower awards than lawsuits where a business or government agency was a third party defendant. In estimating average losses for crime victims, we removed this effect by relying exclusively on the individual perpetrator coefficient.

Juries are generally instructed to award damages based on the notion of making the victim whole. Victims who shared culpability for the assault - either through an argument leading up to the assault or by somehow precipitating the event itself - were awarded significantly lower damages. This result has several possible explanations. Juries implicitly might be reducing the award to take into account comparative 
fault or negligence. If this were the case, it would be outside the scope of their charge. Some states explicitly allow juries to specify a percentage that represents the amount of comparative fault of each party to such a dispute, and reduce the award accordingly. We analyzed only the gross award, ignoring any such reduction. Regardless of the state law on this point, however, the jury instructions do not include an explicit reduction in the gross award to account for victim involvement. An alternative explanation that is consistent with economic theory is that juries reason that victims who had some degree of comparative fault display a higher tolerance for risk and a lower value of their own quality of life by their actions. Thus, an individual who provokes a fight in a bar requires a lower amount of compensation (all else equal) than someone who is mugged on the street by a stranger. This is also consistent with the well-known finding that individuals are willing to accept a higher degree of self-imposed risk than risk that is forced upon them involuntarily [33].

\section{Fear of injury or death}

A crime victim may not be physically harmed and yet suffer from emotional trauma as a result of the fear of injury or death. Although the emotional trauma may be transitory for some victims, to others it may be debilitating. From the data, we could estimate the non-economic loss associated with pure 'fear' or 'risk of death' in the absence of any physical harm in two ways. Our first method was to recalculate the pain and suffering estimates by setting the variables that indicate actual physical harm equal to zero and the variable indicating 'no physical contact' equal to 1 . Out-of-pocket dollar losses were set to $\$ 15$, a value for assaults without physical injury that excluded all physical injuryrelated costs, but included mental health care costs and associated lost productivity as well as lost productivity due to dealing with the legal system. For an assault victim, this results in a pain and suffering estimate of $\$ 1,609$.

Another method is to examine the court cases that did not involve physical injury. Out of the 976 assault cases with jury verdicts, 39 cases were identified where the victim experienced minimal or no physical injury. Seven awards compensated witnesses to assaults or murders. Their mean award was $\$ 72,772$ and the median $\$ 31,094$, with a range from $\$ 21,000$ to $\$ 180,000$. These awards are reportedly only to compensate for the emotional pain and suffering - not for "loss of consortium" which is reported separately. The four lowest awards $(\$ 21,795$ to $\$ 31,094)$ involved sons, daughters or brothers who witnessed an assault against their sibling or parent. Two awards compensated parents who witnessed their children being killed and one a wife who witnessed an assault against her husband; they ranged from $\$ 76,183$ to $\$ 181,962$, with a mean of $\$ 136,048$.

The remaining 32 cases involved plaintiffs who were personally attacked but no physical contact resulted. Eighteen involved psychological trauma that was not described as severe (i.e., PTSD and "severe" emotional trauma were not mentioned). These cases were comparable to Cohen's [9] fear estimates from ten Louisiana cases involving transitory fear and no physical injury. However, two of these cases involved arguments where there were allegations of assault by both parties to the dispute and awards were less than actual out of pocket costs. Those cases were eliminated. The resulting 16 cases had a mean award of $\$ 10,404$ and median of $\$ 4,170$.

The final 14 cases involved significant psychological trauma or PTSD (in some cases they also involved some minor physical injury). Compensatory damage awards varied considerably, from $\$ 472$ to $\$ 669,014$. The mean award was $\$ 167,972$ and the median $\$ 77,500$.
The standard errors on this small collection of cases are so large that the estimates are not very useful. Moreover, the cases are not representative of crime victims overall, and we cannot adjust them for population characteristics of crime victims. Thus, for purposes of making inferences about large samples or national estimates of the cost of fear and risk of death, the first regression-based methodology is preferable.

\section{Discussion and limitations}

The largest limitations of this analysis are the questionable representativeness and age of the JVR data. The data do come primarily from a sweet-spot period when JVR was trying to achieve representativeness. More importantly, we used NCVS data and national data on medical and wage losses rather than JVR data in estimating average losses. The incomplete breakdown of damages awarded in some JVR cases also is problematic. Our ability to predict damages well also was higher for physical than sexual assault. In addition, if juries have changed their assessment of the monetary value of noneconomic damages significantly over the years, the use of jury award data that are now 25-30 years old might be problematic.

Although this paper is new, NCVS-based estimates using its regression equations are not. Without journal publication, they have been used in the main estimates of criminal victimization costs in the U.S. since 1996 [12,34,35].

Comparing our estimates to other estimates, our ratio of values for sexual to medically treated physical assault (3.1) is close to the ratio of 3.4 in [36] based on a survey about willingness to pay for crime reduction. The physical assault estimate of the percentage of quality of life lost also is within $1 \%$ of an estimate based on the widely cited impairment fractions used in Cohen and Miller's regressions [12,3739]. All of those estimates, however, are out of sync with Roman's jury award analysis [15] which estimated the damages from a physical assault with injury exceeded those from a sexual assault. Its sexual assault award estimates (including medical, work loss, and noneconomic damages), however, were similar to ours, $\$ 171,000$ [13] versus our $\$ 209,400$, both well below Cohen et al's $\$ 319,000$ estimate [36] (all stated in 2015 dollars).

It is hard to judge why Roman's estimates differ from ours because neither the dissertation [15] nor a book-chapter summary [40] tabulate mean award by crime type in the raw data. However, a few reasons are apparent. First, Roman used National Incident-Based Reporting System (NIBRS) data for criminal victimization details that are based on 10 states (Colorado, Idaho, Iowa, Massachusetts, Michigan, North Dakota, South Carolina, Utah, Vermont, and Virginia); while jury awards were predominantly based on two large states (California and New York, representing $2 / 3$ of their sample) and four large cities (Chicago, Houston, Seattle, and St. Louis). Neither of these samples is nationally representative. He also reports an overall mean award of $\$ 1.2$ million and median of $\$ 147,00$ - substantially higher than our sample. Second, the use of NIBRS data means the assault estimates are based on the $60 \%$ of assaults with injury that NCVS estimates are police-reported, including $75 \%$ of the aggravated assaults with injury and $55 \%$ of the simple assaults with injury. Our estimates from NCVS also include cases not reported to the police, which more often are the less severe and less costly simple assaults. Third, our assault estimates exclude fatal assaults, but Roman's include them. We estimate that excluding them would reduce Roman's estimated damages per assault with injury by roughly $25 \%$. Fourth, Roman's injury type classification does not include "sexual penetration." Rather, rapes are priced just on 
their associated physical injuries. NCVS estimates that at least $54 \%$ of rapes would have the injury variable coded as none, with the likely coding questionable for another $19 \%$ who said they were bruised but received no treatment, even at home.

\section{Conclusion}

This paper examined over 1,250 jury awards compensating survivors of intentional assaults. We included compensatory damages designed to make victims whole but excluded punitive damages ostensibly designed to punish defendants. We found that jury awards are predictable, although they are highly variable. Nevertheless, one can empirically identify the factors that lead to higher or lower awards and the relationship between such factors as physical injuries, medical costs, lost wages, and the ultimate jury award. We also found some evidence of a deep-pocket effect and that comparative fault is taken into account when awarding damages.

Economists have devised several indirect techniques to estimate the monetary value of noneconomic losses resulting from nonfatal injury. Most studies have focused on estimating what consumers are willing to pay (and actually pay) to reduce injury risk [42]. These techniques have been applied by several authors to criminal victimization [36]; see [42] for a review of this technique and other studies using willingnessto-pay and a comparison of other methods to estimate crime costs. An alternative approach is to examine the jury system itself, which is the method that society uses to compensate for noneconomic harms. The jury award approach has a following in both the academic and policy arenas. Estimates from it are built into the values used in regulatory analysis by the Consumer Product Safety Commission [19-20], and recently by the U.S. Department of Justice in regulations designed to reduce prison rape [43]. Although the underlying theoretical foundations of jury awards and willingness to pay are not necessarily the same, some analysts believe "jury damage awards can be a proxy for the value of lost life or functioning [44]." Some theorists, however, have questioned the advisability of awarding noneconomic damages based on both the perverse incentives created and the fact that ex ante, individuals might not prefer to have such compensation schemes [45]. Jury awards are designed for ex post compensation, not ex ante willingness-to-pay. In theory, willingness-to-pay should be smaller than willingness-to-accept, as it is bounded by a wealth constraint [46]. However, jury awards are not measuring willingness-to-accept directly; they are a measure of society's willingness to compensate victims. As discussed in ref. [42], willingness-to-pay estimates based on public surveys include not only losses to victims, but also the "fear of crime" to non-victims, as well as costly avoidance behavior that non-victims might take. Thus, it is not surprising that the jury award method yields lower crime cost estimates than the willingness-to-pay approach -where the former is one piece of a "bottoms up approach" to estimating the social cost of crime and the latter is a "top down" approach that attempts to fully estimate social costs [42]. Further comparisons of these approaches and some of the main critiques in the context of estimating the cost of crime can be found in Dominguez and Raphael [47] and Cohen [48]. Regardless, the study of jury awards provides useful insights into the value that society places on social ills such as crime.

In addition to being of interest to academics and policy analysts, the study of jury awards can be of value to forensic economists. Although it is doubtful that a jury would be permitted to hear evidence on what typical jury awards are in cases similar to the one they are hearing, jury award data can be used to help educate an attorney, plaintiff, or defendant on the expected value of their case. This can be particularly useful in mitigating unrealistic plaintiff expectations or in the process of settling a case. Many insurance company adjusters use JVR data routinely and a plaintiff can similarly use the data to check their demands are appropriate. This can be particularly useful in unusual cases that do not involve very large out-of-pocket dollar losses - such as rape or sexual assault or other incidents where the primary injury is psychological. Although we do not know if this would be allowed in many courts, in one instance, one author of this article was called upon to provide testimony in a case involving a rape victim. The economist provided testimony that psychological trauma in rape cases is common, juries routinely award damages far in excess of dollar losses in these cases, and that academic research has used these jury award values to place dollar values on rape. Whether or not the judge would have allowed such testimony, both attorneys indicated that the economist report was instrumental in settling the case.

Finally, jury award research has proven valuable in some instances where a judge or appeals court is considering whether or not to reduce a jury award. In several cases, one author of this article has provided an affidavit to a court comparing the award in the case at issue to awards around the country with similar facts. This information was then part of the record the judge could use in determining whether a jury's award was unreasonable.

${ }^{\star}$ Supported under award \#90-IJ-CX-0050 from the National Institute of Justice, Office of Justice Programs, U.S. Department of Justice and National Institute on Drug Abuse grant number 4R44DA040318 - 02. Additional support for this research was received from the Dean's Fund for Summer Research, Owen Graduate School of Management, Vanderbilt University. Points of view and content in this article are those of the authors and do not necessarily represent the official position of the funding agencies. We thank Al Bell, John Douglass, Patrick Grant and Kent Rogers for their able research assistance, and Colin Loftin and Brian Wiersema for their valuable comments and suggestions. Despite their assistance, all remaining errors are the responsibility of the authors.

\section{References}

1. Kritzer HM, Liu G, Vidmar N (2014) An exploration of noneconomic damages in civil jury awards. William \& Mary Law Review 53: 971-1027,

2. Vidmar N (1998) The performance of the American civil jury: An empirical perspective. Arizona Law Review 40: 849-899.

3. Kakalik JS, Pace NM (1986) Costs and compensation in tort litigation. Santa Monica, CA: Rand Corporation.

4. Daniels S, Martin J (1995) Civil juries and the politics of reform. Chicago, IL: Northwestern University Press.

5. Viscusi WK (1988) Pain and suffering in product liability cases: Systematic compensation or capricious awards? International Review of Law and Economics 8 : 203-207.

6. Viscusi WK (1991) Reforming products liability. Cambridge MA: Harvard University Press.

7. Wissler RL, Evans D, Hart AJ, Morry MM, Saks MJ (1997) Explaining 'pain and suffering'awards: The role of injury characteristics and fault attributions. Law \& Human Behavior 21: 181.

8. Diamond SS, Saks MJ, Landsman S (1998) Juror judgments about liability and damages: Sources of variability and ways to increase consistency. DePaul Law Review 48: $301-326$

9. Cohen MA (1988) Pain, suffering and jury awards: A study of the cost of crime to victims. Law and Society Review 22: 237-255.

10. Rajkumar AS, French MT (1997) Drug abuse, crime costs, and the economic benefits of treatment. Journal of Quantitative Criminology 13: 291-323. 
11. McCollister KE, French MT, Fang H (2010) The cost of crime to society: New crimespecific estimates for policy and program evaluation. Drug and Alcohol Dependence 108: 98-109.

12. Miller TR, Cohen MA, Wiersema B (1996) Victim costs and consequences: A new look. Research Report NCJ-155282. Washington DC: National Institute of Justice.

13. Cohen M, Miller TR (2003) Willingness to award non-monetary damages and the implied value of life from jury awards. International Review of Law and Economics 23: $165-181$.

14. Smith S, Zaloshnja E, Miller TR, Smith D, Spicer RS (2008) Jury verdicts in drunken driving cases. Review of Law and Economics, 4:1, article 22.

15. Roman JK (2009) What is the price of crime? New estimates of the cost of criminal victimization. PhD Dissertation, University of Maryland School of Public Policy.

16. Mayhew P (2003) Counting the costs of crime in Australia. Australian Institute of Criminology, available at: http://www.aic.gov.au/media_library/publications/tandi pdf/tandi247.pdf.

17. Easton S, Furness FH, Brantingham P (2014) The cost of crime in Canada. Simon Fraser Institute, available at: https://www.fraserinstitute.org/sites/default/files/cost-ofcrime-in-canada.pdf.

18. Carrington F, Rapp JA (1989) Victims' rights: law and litigation. New York: Matthew Bender \& Co.

19. Lawrence BA, Spicer RS, Miller TR (2015) A fresh look at the costs of non-fatal consumer-product injuries. Injury Prevention 21: 23-29.

20. Lawrence BA, Miller TR, Jensen AF, Fisher DA, Zamula W (2004) Estimating the costs of non-fatal consumer product injuries in the United States. Injury Control and Safety Promotion 7(2): 97-113.

21. Kritzer H (2004) Advocacy and rhetoric vs. scholarship and evidence in the debate over contingency fees: A reply to Professor Brickman. Washington University Law Quarterly 82: 477-507.

22. Daniels S, Martin J (1986) Jury verdicts and the "crisis" in civil justice. Justice Systems Journal 11: 321-327.

23. Localio AR (1985) Variations on $\$ 962,258$ : The misuse of data on medical malpractice. Law, Medicine and Health Care 13: 126-128.

24. Tabarrok A, Helland E (1999) Court politics: The political economy of tort awards. Journal of Law and Economics 42: 157-188.

25. Bovbjerg RR, Sloan FA, Blumstein JF (1989) Valuing life and limb in tort: Scheduling 'pain and suffering.' 83 Northwestern University. Law Review 83: 908-976.

26. Bovbjerg RR, Sloan FS, Dor A, Hsieh CR (1991) Juries and justice: Are malpractice and other personal injuries created equal? Law and Contemporary Problems 54: 5-42.

27. Rabin RL (2011) The pervasive role of uncertainty in tort law: Rights and remedies. DePaul Law Review 60(2): 431-452, available at: http://via.library.depaul.edu/lawreview/vol60/iss $2 / 9$

28. Litan RE, Winston C (1988) Policy options. Liability: Perspectives and Policy. In: Litan R, Winston C (eds.) Washington, D.C.: Brookings Institution, 223-241.

29. Abel R (2006) General damages are incoherent, incalculable, incommensurable, and inegalitarian (but otherwise a great idea). DePaul Law Review 55: 253-329.

30. Special Section: Assessing economic damages in personal injury and wrongful death litigation: articles by state. Journal of Forensic Economics, various years.

31. Barkai J, Kent E, Martin P (2006) A profile of settlement. Court Review 42: 34-39.
32. US Supreme Court (1994) McDermott, Inc. v. AmClyde, 511 U.S. 202, 216.

33. Kunreuther H, Easterling G (1992) Gaining acceptance for noxious facilities with economic incentives. In: Bromley D, Segersen K (eds.), The Social Response to Environmental Risks.

34. Yang J, Miller TR, Zhang N, LeHew B, Peek-Asa C (2014) Incidence and cost of sexual violence in Iowa. American Journal of Preventive Medicine 47: 198-202.

35. Miller T, Fisher D, Cohen M (2001) Costs of juvenile violence: Policy implications Pediatrics 107(1), electronic edition, e3: 1-7.

36. Cohen MA, Rust R, Steen S, Tidd S (2004) Willingness-to-pay for crime control programs. Criminology 42: 86-106.

37. Miller TR, Pindus N, Douglass J, Rossman S (1995) Databook on nonfatal injury -incidence, costs, and consequences. Washington DC: The Urban Institute Press.

38. Zaloshnja E, Miller TR, Romano E, Spicer R (2004) Crash costs by body part injured, fracture involvement, and threat-to-life severity, United States, 2000. Accident Analysis \& Prevention 36: 415-427.

39. Spicer RS, Miller TR, Hendrie D, Blincoe LA (2011) Quality-adjusted life years lost to road crash injury: Updating the Injury Impairment Index. Annals of Advances in Automotive Medicine 55: 365-377.

40. Roman JK (2011) How do we measure the severity of crime? New estimates of the cost of criminal victimization. Measuring Crime and Criminality: Advances in Criminological Theory, 17. In: MacDonald J (ed.) Piscataway, NJ: Rutgers University Press, 30-77.

41. Viscusi WK, Aldy JE (2003) The value of statistical life: A critical review of market estimates throughout the world. Journal of Risk and Uncertainty 27: 5-76.

42. Cohen MA (2010) Valuing Crime Control Benefits Using Stated Preference Approaches. Chapter 4 (pp. 73-118) in Cost-Benefit Analysis and Crime Control. In: Roman JK, Dunworth T, Marsh K (eds.) Washington, DC: Urban Institute Press. Draft chapter available at: http://ssrn.com/abstract=1091456.

43. U.S. Department of Justice (2012) Prison Rape Elimination Act, Regulatory Impact Assessment, available at: http://ojp.gov/programs/pdfs/prea_ria.pdf.

44. Crowley DM, Jones DE (2016) Financing prevention: opportunities for economic analysis across the translational research cycle. Translational Behavioral Medicine 6: $145-152$

45. Viscusi WK (2008) The flawed hedonic damages measure of compensation for wrongful death and personal injury. Journal of Forensic Economics 20: 113-135.

46. Cook PJ, Graham DA (1977) The demand for insurance and protection: The case of irreplaceable commodities. Quarterly Journal of Economics 91: 143-56.

47. Dominguez P, Raphael R (2015) The role of the cost-of-crime literature in bridging the gap between social science research and policy making. Criminology \& Public Policy 14: 589-632.

48. Cohen MA (2016) The "cost of crime" and benefit-cost analysis of criminal justice policy: understanding and improving upon the state-of-the-art. Available at http://ssrn. com/abstract $=2832944$

49. Lauritsen J (2012) Transcript of "Violent repeat victimization: Prospects and challenges for research and practice". Washington DC: National Institute of Justice.

50. Sedlak AJ, Mettenburg J, Basena M, Petta I, McPherson K, Greene A, Li S (2010) Fourth national incidence study of child abuse and neglect (NIS-4): Report to Congress. Washington DC: Administration for Children and Families.

Copyright: (C2017 Miller TR. This is an open-access article distributed under the terms of the Creative Commons Attribution License, which permits unrestricted use, distribution, and reproduction in any medium, provided the original author and source are credited. 